\title{
A Case Study on Structural Failure of Reinforced Concrete Beam-Column Joint After the First Significant Earthquake Impact in Malaysia
}

\author{
Reventheran Ganasan ${ }^{1,2^{*}}$, Chee Ghuan Tan ${ }^{1}$, Zainah Ibrahim ${ }^{1}$, Fadzli \\ Mohamed Nazri ${ }^{3}$, Yew Hoong Wong ${ }^{4}$
}

${ }^{1}$ Department of Civil Engineering, Faculty of Engineering, University of Malaya, Jalan Universiti, 50603 Kuala Lumpur, MALAYSIA

${ }^{2}$ Department of Civil Engineering Technology, Faculty of Engineering Technology, University of Tun Hussein Onn Malaysia, 84600 Pagoh, Johor, MALAYSIA

${ }^{3}$ School of Civil Engineering, Engineering Campus, Universiti Sains Malaysia, 14300 Nibong Tebal, Pulau Pinang, MALAYSIA

${ }^{4}$ Department of Mechanical Engineering, Faculty of Engineering, University of Malaya, Jalan Universiti, 50603 Kuala Lumpur, MALAYSIA

*Corresponding Author

DOI: https://doi.org/10.30880/ijie.2020.12.08.028

Received 25 July 2019; Accepted 07 May 2020; Available online 15 September 2020

\begin{abstract}
This paper presents a case study regarding failures of structural buildings which occurred in Malaysia after the first significant earthquake event dated on June 5, 2015. Ranau is a locality situated in Sabah, Malaysia on the island of Borneo. The seismic activity was triggered when an earthquake with a magnitude of 5.9 afflicted Ranau, including seven other districts that also felt the tremors. Even though the impact of magnitude was undisputedly not high, the severity level of damages was found to be absolute (irreparable) in the structural RC beam-column joints and soft-storey buildings. Most of the buildings in Malaysia were built without the consideration of seismic design, and thus a major factor in structural failure. The earthquake has directed the seismic demand, while the total displacement was concentrated at the weakest floor that caused more damage to the building. This paper shows the causes of beam-column joint damages and explains the proposed (to-date) strengthening methods. Future studies related to seismic activities are in need to analyse the performance of the existing design of structural RC members and propose seismic design in Malaysia.
\end{abstract}

Keywords: Beam-column joints, Ranau earthquake, seismic activity, soft-storey, strengthening method

\section{Introduction}

Malaysia lies in low to moderate seismic region, where buildings and infrastructures are not seismically built. Areas of low to moderate seismicity have been discovered to be more prone to damages than areas of high seismicity [1]. Throughout the world, a majority of old reinforced concrete (RC) building structures are designed and built only for gravitational load without weighing in active seismic areas [2]. Recently, the Malaysian construction industry has 
begun adhering to the design guideline imposed by the British Standards [3]. Nearly all RC buildings in Malaysia are designed and built in accordance to BS 8110:1:1997 [4]. However, an unspecific provision may exist in detailed design made on beam-column joint when subjected to seismic loading [5]. Considering beam-column joint in RC building is crucial in seismic excitations [6] especially for the soft-storey design mechanism. The existing soft-storey buildings were built before any seismic design was introduced, and thus failures, such as "weak-column/strong-beam" mechanisms were often observed [7-9]. The formation of plastic hinges for ductility and lateral strength was limited due to the incoherent and deficient designs of these existing buildings [10]. Engineers at present times appear to be more concerned regarding the lack of seismic and earthquake consideration for the current building design procedure because these problems keep occurring in Malaysia [11]. Some local authorities and non-government organisation (NGO) have offered assistance to develop, promote and enforce the National Annex to Eurocode 8 pertaining to the design of structures for earthquake resistance [12]. Therefore, Malaysia National Annex to Eurocode 8 was established in 2017 by Department of Standards Malaysia under the Standard and Industrial Research Institute of Malaysia (SIRIM) Berhad which focused in general design for new buildings however no strengthening method was explained for the existing or current structural buildings [13].

\section{Low to Moderate Seismic Activities in Malaysia and Other Prone Regions}

The original tectonic plate and fault lines show that Malaysia falls under the low-seismicity group [14]. Geographically, Malaysia is located near the Australian Plate, where it is actively placed south-westward underneath the Eurasian Plate in a stable Sunda platform [15]. However, a series of multiple intense earthquakes recently has changed the tectonic positioning in the Southeast Asian region, including Peninsular Malaysia [16] and East Malaysia. Sabah is an exception because this province belongs to the moderate seismicity prone region [17]. Numerous tremors have been reported and felt several times due two highly-active seismic plates, namely the Indian-Australian Plate and the Philippine Plate as shown in Fig. 1 [18]. These seismic sources (Sumatran and Philippine earthquakes) caused the shaking of medium and high-rise buildings [11], [19].

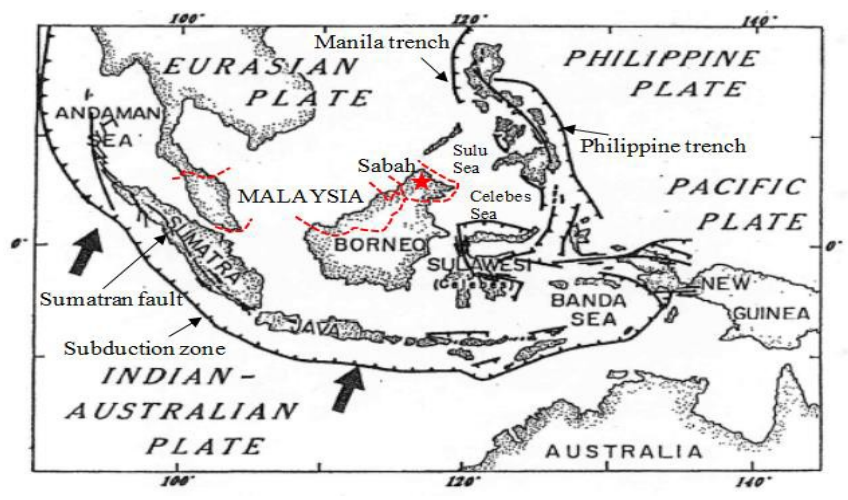

Fig. 1 - Sumatran fault lines and subduction zone of the Indian-Australian Plate into the Eurasian Plate [18]

Although Malaysia is not located near the seismic prone areas, buildings constructed on soft soils are often exposed to far-field earthquakes generated from faults and subduction zones from the Philippines and Sumatra, particularly in the east Malaysia in Sabah. The occurrence of frequent earthquakes in the low seismic regions in the last few decades has led researchers to investigate seismic hazard in low seismic regions around the world, such as Thailand, Malaysia, Singapore, Korean, Germany, Belgium, Spain and Iceland [20-26]. Their studies were based on the historical evidence of extensive damages and losses caused by a predominantly stable intra-plate [27]. Insufficient documentation and lack of experience to damaging earthquakes in low seismic regions resulted in improper code regulations by the authorities in the development of structures in a few countries of this region. If not carefully handled, then these improper code regulations may lead to serious glitches in the future, especially for buildings and infrastructures that are not seismically designed. One classic example is the 1989 intra-plate earthquake in Newcastle, Australia, which was the first Australian earthquake recorded in history to claim human lives. Australia was formerly classified as a seismic-free zone, however it suddenly experienced a magnitude 5.5 earthquake, which prompted substantial changes in the seismic design provisions of the Australian Standard [28]. The earthquake claimed the lives of 13 people, incurred damages to 50, 000 buildings, and demolition of 300 buildings [29]. Although the intensity of this earthquake was considered to be moderate, it exerted significant damages and consequences to the city of Newcastle. Inadequate maintenance, poor condition, and weak foundation of non-seismically designed old buildings appear to be the major reasons for the damages. The recent earthquake occurrences in Sabah share some similarities to the earthquakes that took place in Australia. Most of the buildings were not seismically designed and many old buildings were located in the down-town of Sabah. Based on the Newcastle earthquake scenario, the buildings in 
Malaysia may also suffer from small to moderate intra-plate earthquakes. Although earthquakes triggered by intra-plate faults have small magnitudes, predicting such earthquakes is extremely difficult and should not be underestimated.

Therefore, an estimated seismic hazard for Malaysia was modelled by using probabilistic seismic hazard assessment (PHSA) based on the reference data of historical seismological ground motions obtained from respective distant earthquakes [30], [31]. Prior PHSA studies concluded that the peak of ground acceleration (PGA) values across Peninsular Malaysia probably fell between 0.02 and $0.10 \mathrm{~g}$ with an approximation of a 475/500-year return period [32, 33]. On the contrary, the PGA values at East Malaysia was around $0.07 \mathrm{~g}$ (Sarawak) and $0.12 \mathrm{~g}$ (Sabah) with a 500-year return period [34], [35]. Fig. 2 illustrates the proposed seismic hazard zonation (minimum effective peak of ground acceleration for a notional return period of 475 years) for the whole of Malaysia [36].

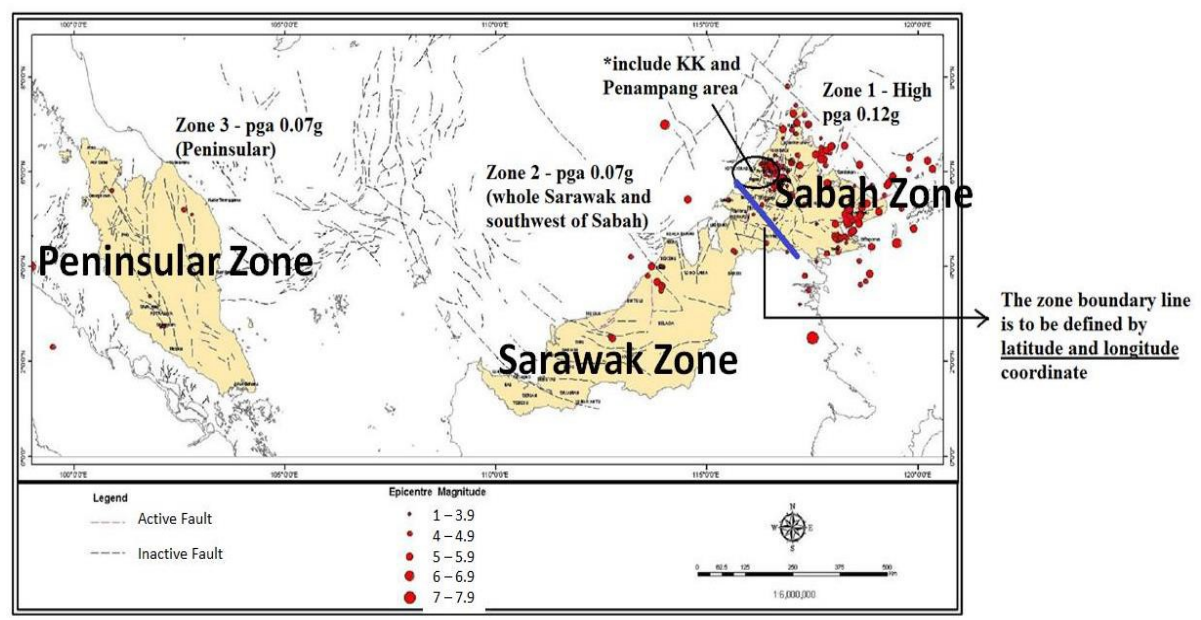

Fig. 2 - Seismic hazard zonation across the whole of Malaysia [36]

Through this proposed seismic zonation map, the local authorities and other NGOs have been eagerly promoting and inviting all engineers and consultants to comprehend the technical basis of the key features embedded in the National Annex draft to be implemented in Eurocode 8 Malaysia. Despite the development of a hazard map, the modelled seismic hazard map regions of low seismicity seem to be unfavorable due to insufficient and unpredictable earthquake wave analyses [37].

\section{Soft-Storey Buildings in Prone Regions of Seismic Activities}

Soft-storey, which is also known as weak-storey, is defined as a building that has substantially less resistance or stiffness, as well as inadequate ductility or energy absorption capacity to resist earthquake-induced building stresses. Soft ground storey is the most common feature of soft-storey irregularity or flexible storey [38]. This building usually has a large number of non-structural rigid components, such as masonry walls attached to the columns of an RC frame structure, wherein the ground storey has empty walls, when compared to those in the upper floors. An example of softstorey is the "open floor" in the ground storey of modern residential buildings. The rigid non-structural components limit the deformation ability of columns, thus modifying the structural performance of the building to horizontal forces. A building is considered as soft-storey when the lowest floor is $70 \%$ less stiff than the upper floors [39, 40]. Several studies on earthquakes had been based on Bhuj earthquake (2001), North Kashmir earthquake (2005), Indonesia earthquake (2004), Haiti earthquake (2010), and Japan earthquake (2011), which presented that numerous existing RC buildings were vulnerable to damage or even total collapse due to vertical stiffness irregularities [41]. The major failure found in these buildings was at the beam-column joint area, wherein the failures included snapping of lateral ties, crushing of core concrete, and buckling of longitudinal reinforcement bars.

Evidently a study related to structural damages from the 2009 L'Aquila earthquake reported [42], via in-situ observation, the bare frame at ground level results in soft-storey mechanism and brittle collapse. A similar observation was also reported during the Lorca earthquake in 2011, where the soft-storey mechanism was developed by different strengths and lateral stiffness of the ground floor with respect to the upper floor [43]. The weak-column strong-beam behaviour and poor detailing in beam-column joints were observed during the 2011 Van, an earthquake in Turkey [44]. An example of case study occurred in Tucacas last September 12, 2009, which is approximately $50 \mathrm{~km}$ from the epicentre of the earthquake with a magnitude of $\mathrm{Mw}$ 6.2. All the ground storey columns experienced severe damages (see Fig. 3), while only slight damages were noted at the beams due to the presence of infill wall that restricted the beams from getting deformed in a typical bending shape [45].

The soft-storey effects existed in medium to high-rise buildings in Malaysia during the Ranau earthquake (2015). This effect was mainly caused by differential stiffness of the floor (no masonry wall in a particular floor), differential column height, and discontinuous column (parking floor) in the building, as shown in Fig. 4. During the earthquake, 
this effect led to seismic demand and total displacement, which concentrated on the weakest floor and caused more damages to the building (see Fig. 5). From a structural viewpoint, an optimum conception of a momentum resisting structure involves enforcing a specific path of plastic hinges formation in the structure to minimise damages when subjected to earthquake loading. This favourable behaviour provides the structure with a sufficient amount of ductility to enhance its resisting and stability capacity. The propagation of plastic hinges in a frame under seismic loading reflects complex non-linear behaviour. Many studies have looked into the hinge propagation of soft-storey [46], [47] and retrofit techniques [48], [49]. However, these studies are mostly for seismically-designed buildings that may not be entirely applicable to the buildings erected in Malaysia. The soft-storey effects on hinge propagation mechanism for non-seismically designed buildings are not well explored. Hence, investigating the soft-storey effect on the propagation mechanism of plastic hinges in a non-seismically designed RC building subjected to earthquake loading is indeed necessary.

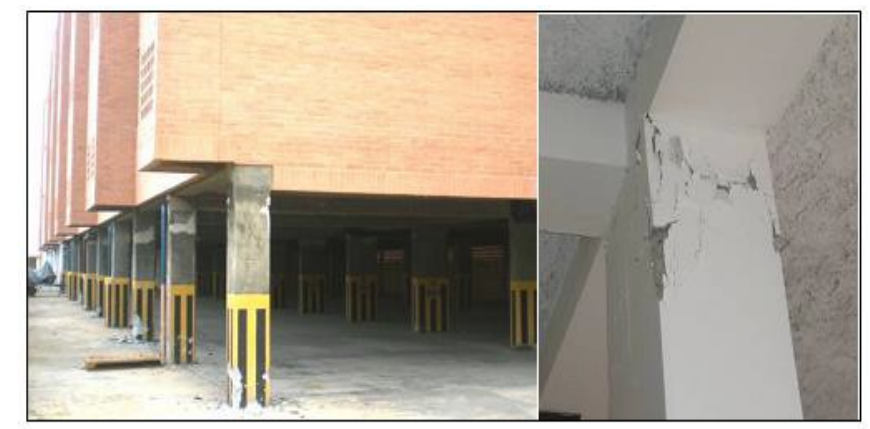

Fig. 3 - A typical soft storey mechanism at the open ground storey [45]

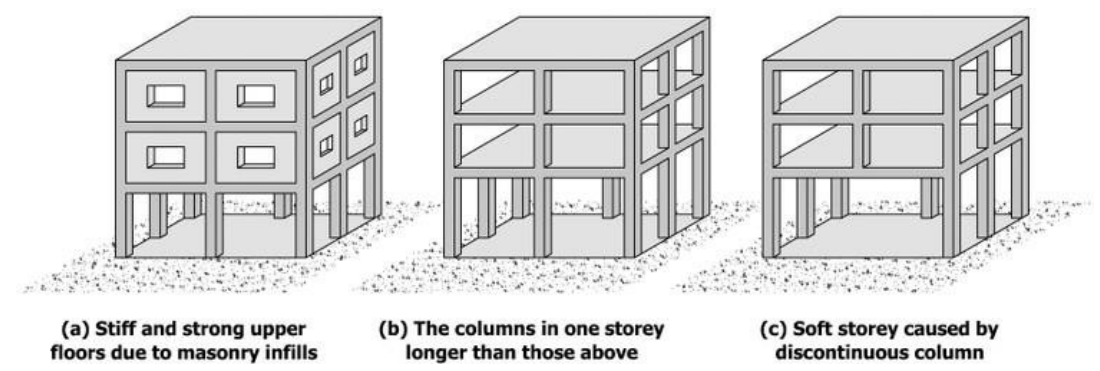

Fig. 4 - Soft-storey caused by (a) stiff and strong upper floors due to masonry; (b) columns in one storey longer than those above and (c) discontinuous column [41]
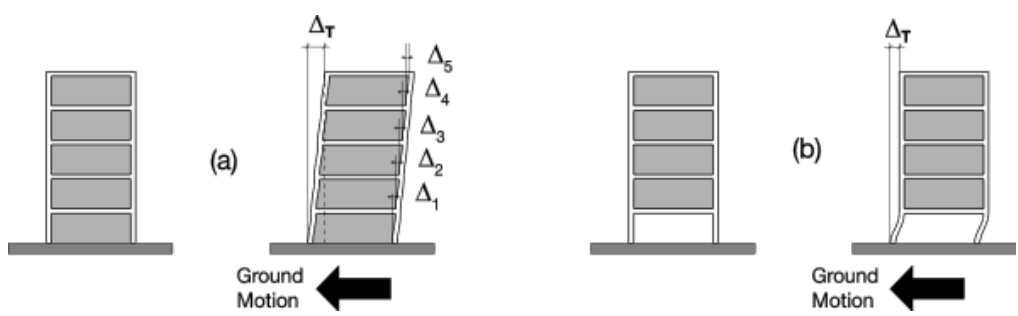

Fig. 5 - Distribution of total displacement generated by an earthquake in: (a) a regular building; and (b) a building with soft-storey irregularity [38]

\section{Case Study in Ranau, Sabah (Earthquake)}

In June 5, 2015, a moderate earthquake with magnitude Mw 5.9 struck Ranau, along with the surrounding villages and cities in Sabah [50]. Although the Ranau earthquake was a moderate earthquake, it was the strongest earthquake recorded in the history of Malaysia since 1976 when Lahad Datu was struck by a magnitude of 5.8. More than 60 buildings from seven districts in Sabah, namely Ranau, Kota Belud, Tuaran, Penampang, Kota Kinabalu, Nabawan and Tambunan, suffered minor to severe damages due to the earthquake and aftershocks. This incident has obliterated the assumption of the local people regarding the existence of serious and damaging earthquakes in the country. Damages in other public buildings, such as mosque, residential quarters, police station, bank, and shopping complex, were reported as well [51]. The earthquake was considered as a near-field earthquake because the epicentre was located only 
approximately $16 \mathrm{~km}$ from Ranau, thereby causing considerable damages to the structures, as reported in previous work $[52]$.

\subsection{Seismo-Tectonic Characteristics of Sabah}

Ranau, Sabah (see Fig. 6) is located on the semi-stable South China Sea Basin [53]. Ranau has been affected by regional earthquakes from the active mobile belts in the Philippines and local earthquakes. Most of the major earthquakes from the Sulu and Celebes seas are constantly felt in Sabah. Based on the earthquake database, more than 221 earthquakes with $\mathrm{Mw}>6$ within $1000 \mathrm{~km}$ from Kota Kinabalu have been felt by Sabah since 1973 [54]. The regional earthquakes derive from the active subduction zones of North Sulawesi Trench, Sulu Trench, Negros Trench, Manila Trench, and Cotabato Trench [55]. From 1897 to 2009, more than 28 to 33 local light to moderate earthquakes were recorded in the mainland and the surrounding sea of Sabah. The magnitudes of these earthquakes ranged from Mw 4.0 to 5.8 and the epicentres were concentrated on the local fault lines in Ranau and Lahad Datu areas [56]. The two main seismic zones trending northeast-southwest occur in Sabah, specifically Ranau Labuk Bay Zone and Semporna Dent Peninsular Zone. Both seismic zones are characterised by northeast-southwest trending reverse faults, which is possibly a south-eastward extension of the Cagayan Thrust and Sulu subduction in the Sulu Sea region. Three light earthquakes were recorded within $100 \mathrm{~km}$ radius of the Ulu Padas Area, where the large dam is assumed to be located. Earthquakes have also occurred near Pensiangan with a magnitude of Mw 4.1, Kuala Penyu (Mw 4.5), and Long Semado in Sarawak (Mw 4.5). The Pensiangan and Long Semado earthquakes were associated with southward extension of the northeast-southwest trending Ranau Labuk Bay seismic zone. The most recent local earthquakes in Sabah since 2015 are summarised in Table 1 [50].

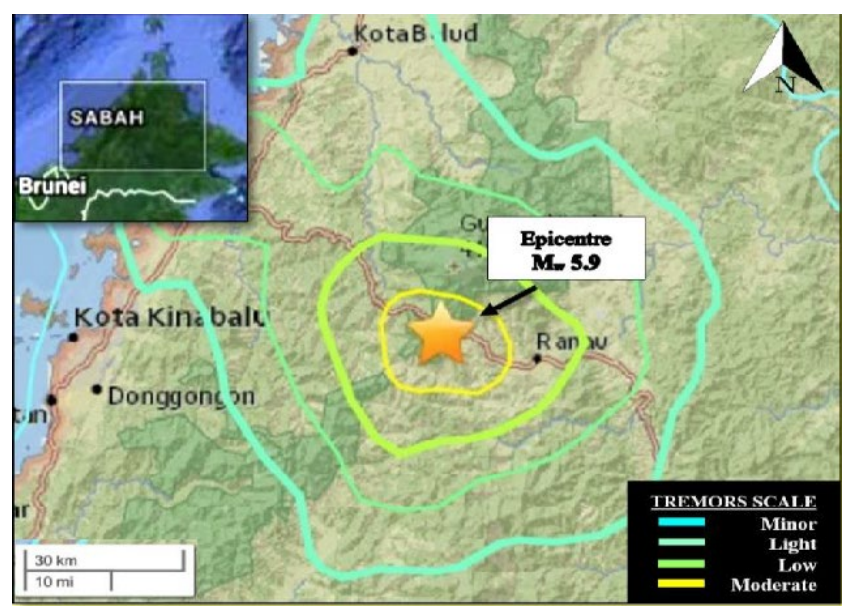

Fig. 6 - Modified map of Ranau, Sabah (Malaysia) [53]

Table 1 - Recent local earthquakes in Sabah since 2015 [50]

\begin{tabular}{|c|c|c|c|c|}
\hline Num & Location & Date & Epicenter Coordinate $\left(^{0}\right)$ & Magnitude $\left(M_{w}\right)$ \\
\hline \multirow[t]{7}{*}{1} & Ranau & 04 Apr 2018 & $6.07,116.62$ & 4.0 \\
\hline & & $29 \operatorname{Mar} 2018$ & $6.1,116.6$ & 3.9 \\
\hline & & 11 Mar 2018 & $6.0,116.6$ & 3.1 \\
\hline & & 09 Mar 2018 & $6.0,116.6$ & 3.1 \\
\hline & & 08 Mar 2018 & $6.1,116.5$ & 3.2 \\
\hline & & 08 Mar 2018 & $6.0,116.6$ & 5.2 \\
\hline & & 07 Apr 2017 & $6.1,116.6$ & 2.6 \\
\hline \multirow[t]{3}{*}{2} & Lahad Datu & 03 Apr 2017 & $4.7,118.6$ & 3.7 \\
\hline & & $29 \operatorname{Mar} 2017$ & $4.8,118.5$ & 3.4 \\
\hline & & $26 \operatorname{Mar} 2017$ & $4.8,118.6$ & 4.2 \\
\hline 3 & Ranau & 31 Jan 2017 & $6.0,116.6$ & 3.4 \\
\hline 4 & North Coast of Sabah & 18 Dec 2016 & $7.3,116.3$ & 3.5 \\
\hline \multirow[t]{2}{*}{5} & Ranau & 29 Nov 2016 & $6.1,116.6$ & 3.3 \\
\hline & & 26 Aug 2016 & $6.05,116.59$ & 4.0 \\
\hline 6 & Lahad Datu & 01 May 2016 & $4.9,118.2$ & 3.5 \\
\hline 7 & Ranau & 16 Apr 2016 & $6.0,116.6$ & 3.0 \\
\hline \multirow[t]{2}{*}{8} & Lahad Datu & 01 Mar 2016 & $4.9,118.2$ & 3.5 \\
\hline & & 16 Feb 2016 & $4.9,118.5$ & 3.3 \\
\hline
\end{tabular}




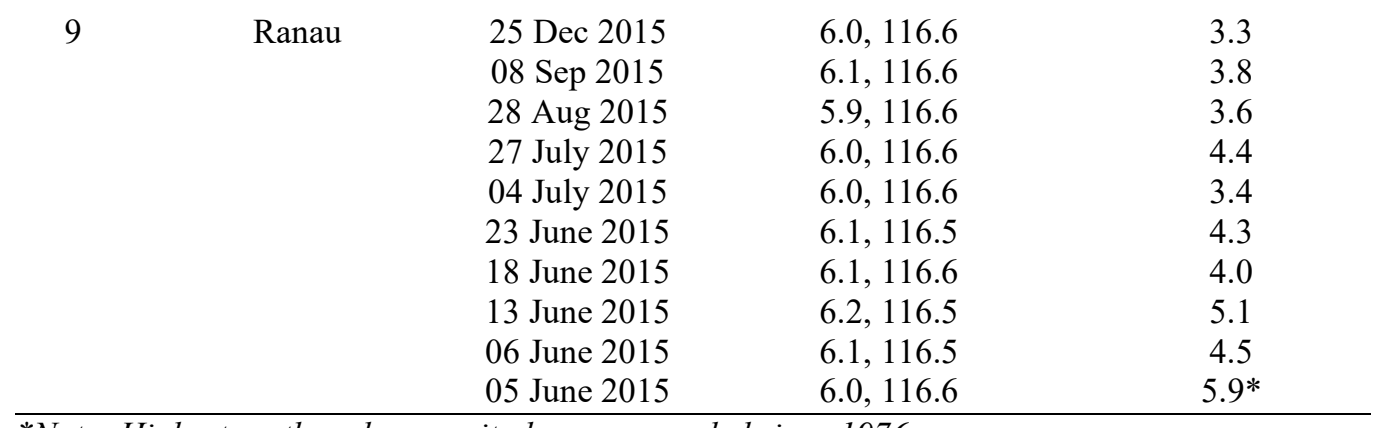

*Note: Highest earthquake magnitude ever recorded since 1976

\subsection{Main Event and Aftershocks}

The main shock motion of the Ranau ground was recorded from Kota Kinabalu Station (north-east direction) located 60 to $70 \mathrm{~km}$ away from the epicentre. The acceleration, velocity, and displacement values in Fig. 7 were tabulated from the raw data obtained from this local station. Maximum acceleration encountered in the North-East direction was $0.124 \mathrm{~g}$ at $7.76 \mathrm{~s}$, whereas the maximum velocity and displacement in horizontal direction were recorded at $5.072 \mathrm{~cm} / \mathrm{sec}$ (at $9.88 \mathrm{~s}$ ) and $0.513 \mathrm{~cm}$ (at $13.88 \mathrm{~s}$ ), respectively.
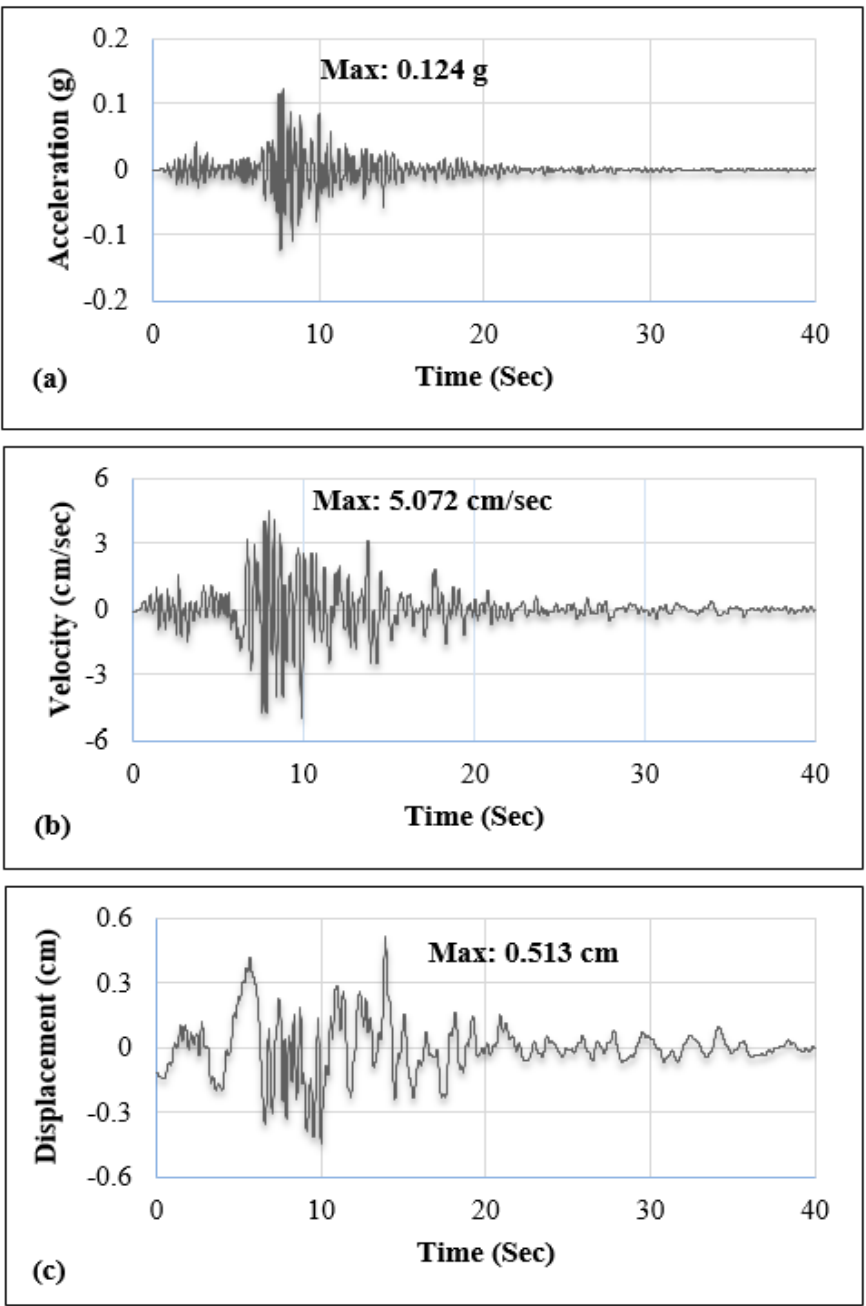

Fig. 7 - (a) acceleration, (b) velocity and (c) displacement of Ranau main shock in the north-east direction

Fig. 8 illustrates the pseudo-spectra of acceleration, velocity, and displacement from Station Kota Kinabalu-NE component of Ranau earthquake with various damping ratios of $0 \%, 5 \%, 10 \%, 15 \%$ and $20 \%$ produced from SeismoSignal version 2016 computational software. As expected from the moderate motion data, the damping ratio of $5 \%$ exhibited maximum acceleration spectra identified as $0.54 \mathrm{~g}$, which was close to $0.2 \mathrm{~s}$. In the horizontal direction, 
the maximum values for velocity and displacement spectra $(\zeta=5 \%)$ fell between $0.3 \mathrm{~s}(23.34 \mathrm{~cm} / \mathrm{s})$ and $0.5 \mathrm{~s}(1.30 \mathrm{~cm})$, respectively. At the period approaching 1.2s, most of the damping ratio lines were connected in the horizontal direction.
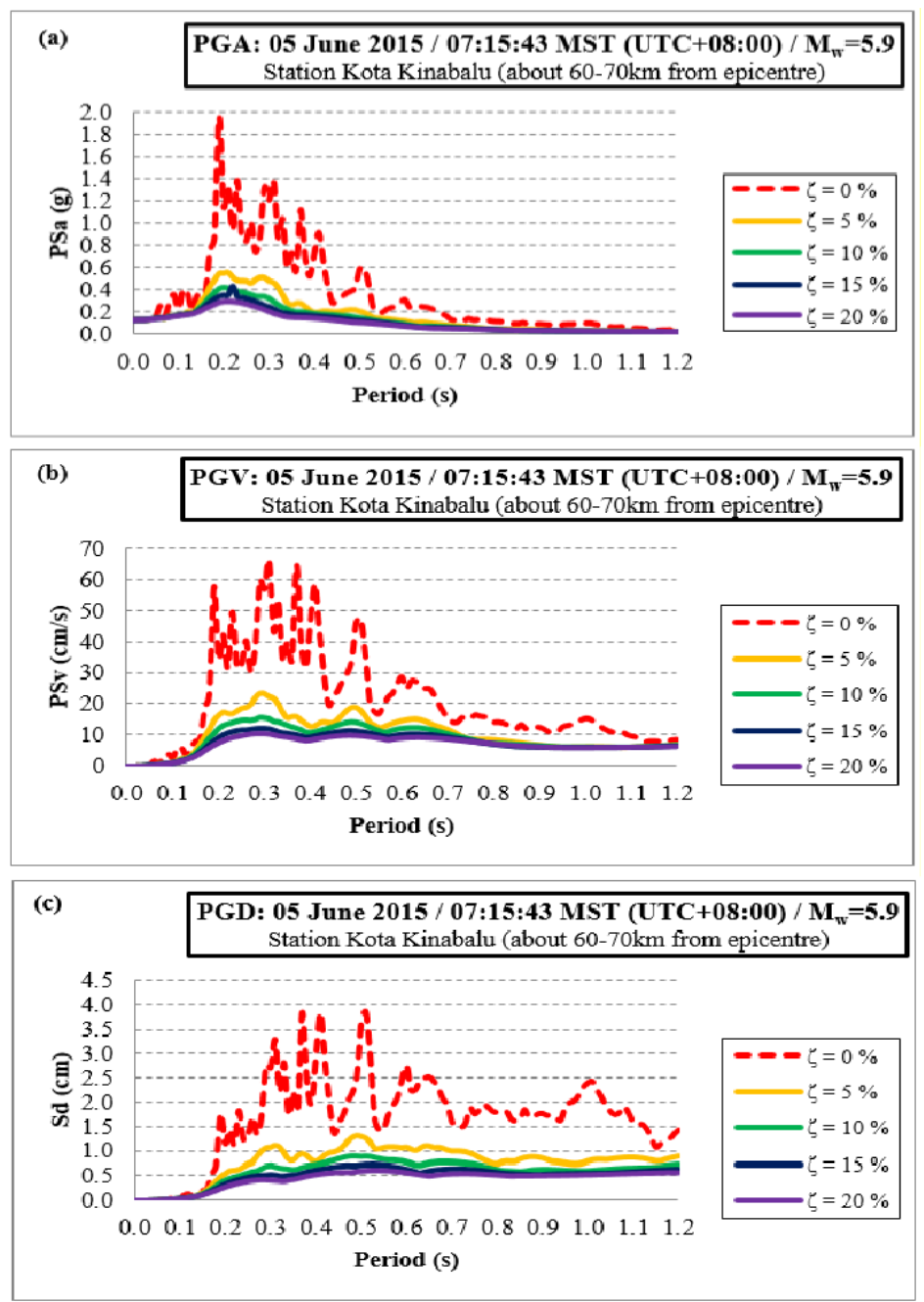

Fig. 8 - Spectral response of the main event for various damping ratios: (a) pseudo-spectrum acceleration (PSa), (b) pseudo-spectrum velocity (PSv) and (c) spectrum displacement (Sd)

Until June 28, a total of 90 repercussion movements of aftershocks were recorded after the main shock that occurred in June 5, 2015. The epicentral conveyance of the main event, and followed by the aftershocks, is portrayed in Fig. 9. Fig. 10 demonstrates the magnitude tremors of the main event, accompanied by the consequential aftershocks on a periodic scale. The magnitudes and the recurrence of post-quake tremor event eventually diminish after the main shock.

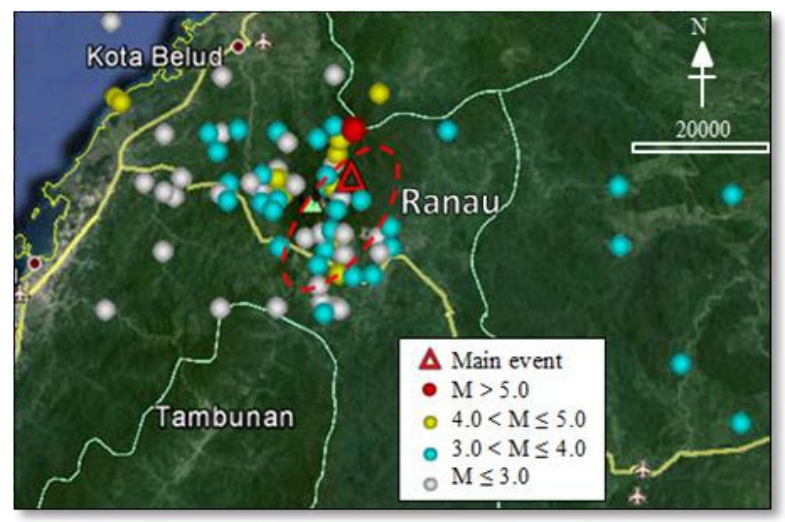

Fig. 9 - Tremors of main shock and aftershocks occurrence in the seven districts 


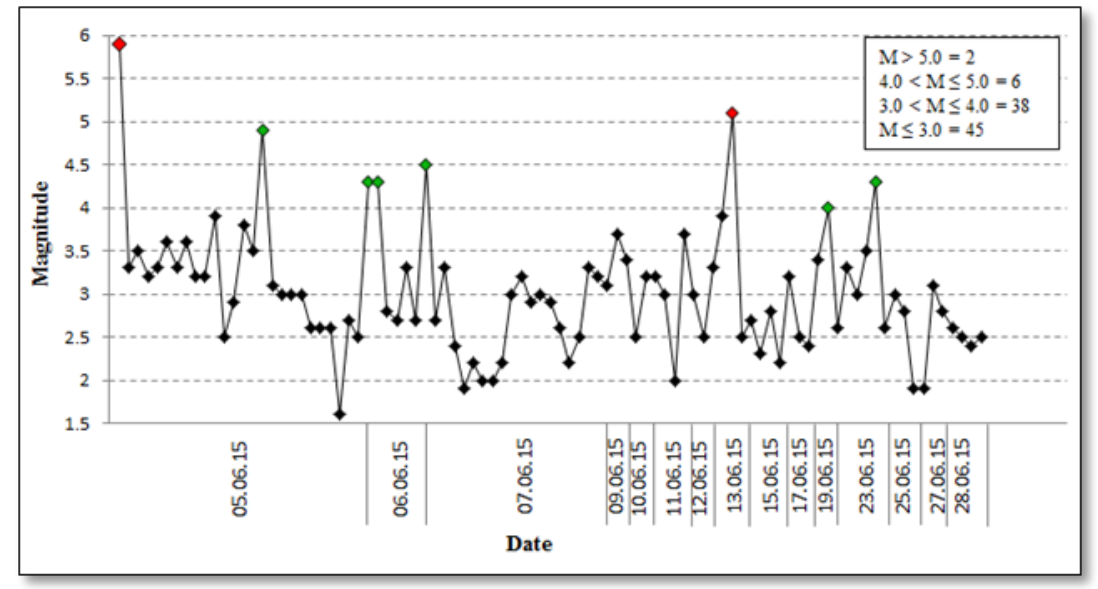

Fig. 10 - Timeline history of main shock event and aftershocks

\subsection{Case Study on Building Structure Damages}

An immediate in-situ survey was conducted to look into several case study buildings after the 5.9 moderateintensity Ranau earthquake. The observation survey was cautiously performed on every site because the severe damages of the buildings may still be harmful and may cause unexpected accidents to the people residing within the area. Before the local Ranau earthquake took place in June 5, 2015, no casualty or major damage was reported in the building from the previous local and regional earthquakes. Only non-structural cracks on buildings in a few cities had been reported [57]-[59]. From all the potential sites found, a total of five sites were selected as case study buildings due to the severely-affected building structures after the main shock. Table 2 presents the summary of case study buildings that are coded as RNU 01 to RNU 05 based on their respective site location. These case study buildings were found to be designed only for gravity load and were typically built for residential usage between the 1990s to early 2000s. Based on the rapid in-situ survey, the damages on the case study buildings caused by the earthquake tremor were observed to be severely damaged especially at the beam-column joints.

Table 2 - Details of all five site locations

\begin{tabular}{cccccc}
\hline Site Code & Latitude & Longitude & Area & Type of structure & Remarks \\
\hline RNU 01 & $6.1^{\circ} \mathrm{N}$ & $116.6^{\circ} \mathrm{E}$ & Ranau & RC frame & Police Quarter \\
RNU 02 & $6.2^{\circ} \mathrm{N}$ & $116.4^{\circ} \mathrm{E}$ & Ranau & RC frame & Secondary School Quarter \\
RNU 03 & $6.2^{\circ} \mathrm{N}$ & $116.5^{\circ} \mathrm{E}$ & Ranau & RC frame & Secondary School Building \\
RNU 04 & $6.1^{\circ} \mathrm{N}$ & $116.5^{\circ} \mathrm{E}$ & Ranau & RC frame & General Hospital Quarter \\
RNU 05 & $6.1^{\circ} \mathrm{N}$ & $116.5^{\circ} \mathrm{E}$ & Kundasang & RC frame & Resort \\
\hline
\end{tabular}

\subsubsection{Damage Inflicted at Beam-Column Joints}

The Ranau earthquake had majorly inflicted damages on the beam-column joints. Enormous cracks and spalling of the concrete cover were noted in those studied areas, as displayed in Fig. 11. It was found that the confinement of reinforcement between the beam-column joints was inexistent in these structures. The reinforcement detailing was found only eligible for gravity load when considering the design buildings based on BS8110-1997. In seismic contemplation, these beam-column joints failed to withstand the lateral load caused by the seismic excitation. In Eurocode 8 [60], Clause 5.4.3.3 states that the horizontal confinement reinforcement in joints of primary seismic beams with columns should be predefined and specified for the critical regions in the columns. Hence, this confinement reinforcement must be placed within the beam-column joints, as proposed for the critical regions in the columns.

A significant increase in ultimate load and ultimate displacement was observed by increasing the amount of confinement reinforcement in the beam-column joints [61]. In some cases, severe cracks were observed at the beamcolumn joint and elongated to the critical regions in the columns, which caused permanent displacement. The columns seemed to display inadequate strength to resist any lateral load induced by the earthquake. This study has identified that less damage was inflicted at the beam because of the effective presence of good tie beams, but not in the column area, as demonstrated in the 2011 Maden (Elazig) earthquake in Turkey [62]. This condition indicates that most of the case study buildings experienced weak-column strong-beam behaviour, which did not comply with the seismic design provision. This behaviour can be interpreted based on severely-damaged and collapsed RC buildings during the 2011 Van earthquake in Turkey [63]. These joints are considered as the weakest link in a structural system due to the distribution of seismic loadings [64]. 

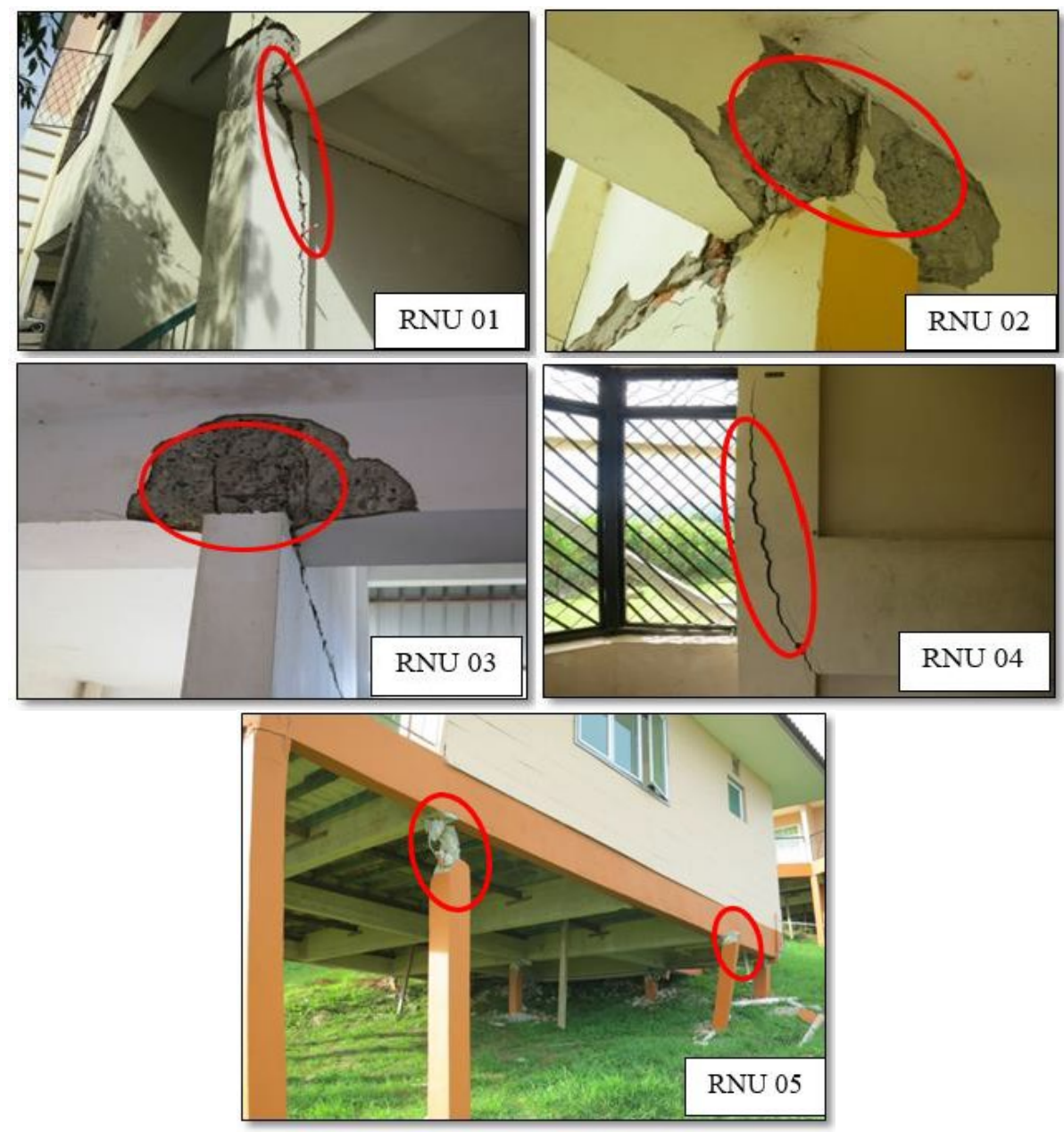

Fig. 11 - Severe damage inflicted on beam-column joints

\subsection{Causes of Failures}

\subsubsection{Soft-Storey Mechanism}

A total of three five-storey residential buildings have been selected and identified to be built without seismic design using RC moment resisting frame. Table 3 summarises the basic structural information, whereas the views are displayed in Fig. 12. These soft-storey buildings, which were coded as RNU 01, RNU 02, and RNU 04, had typical structural configuration with a bare frame located at the bottom part of the building for car park area. These buildings had high influence on soft-storey failure mechanism.

The structural damages on beam-column joints mostly occurred at the bottom storey for all the soft-storey buildings (RNU 01, RNU 02, and RNU 04). This type of failure mechanism was employed when all the inflicted damages were concentrated at the storey (no infill wall or bare frame), which was usually located in the basement area of the building designated for auto stop zone. With the presence of bare frame effect, these storeys had lesser stiffness, when compared with the upper storey with infill wall. Hence, an enormous inter-storey drift ratio could have been experienced by this storey, thus causing severe damages. In a few cases of strong earthquakes, the soft-storey failure mechanism resulted in the total collapse of the bottom storey, as noted in the Kocaeli [65] and Sultandagi earthquakes in Turkey [66].

\subsubsection{Inadequate Reinforcement Arrangements}

This study points out that RNU 05 had undergone many severe damages and collapse of the RC structural column (see Fig. 13). Poor arrangement in transverse reinforcement (links) was the main factor in the buckling and collapse of the column. According to clause 9.5.3(3) [67], the maximum spacing should not exceed 20 times the size of the smallest compression bar or the least lateral dimension of the column $(400 \mathrm{~mm})$. In RNU 04, the lap length found in the column (see Fig. 14) did not adhere to clause 8.7.3 [83], wherein the design lap length between the bars should be greater than $200 \mathrm{~mm}$. Thus, this existing structure caused spalling of the concrete in the joint area. Hence, both of the identified failures resulted in a low quality attribute of concrete binding [68]. A proper basic reinforcement design should be countered in detail before engaging in the seismic consideration depicted in Eurocode 8. 
Table 3 - List of identified soft-storey buildings

\begin{tabular}{cccc}
\hline Site Code & Type of structure & Number of storey & Remark \\
\hline RNU 01 & RC moment resisting frame & 5 & Police Quarter \\
RNU 02 & RC moment resisting frame & 5 & Secondary School Quarter \\
RNU 04 & RC moment resisting frame & 5 & General Hospital Quarter \\
\hline
\end{tabular}
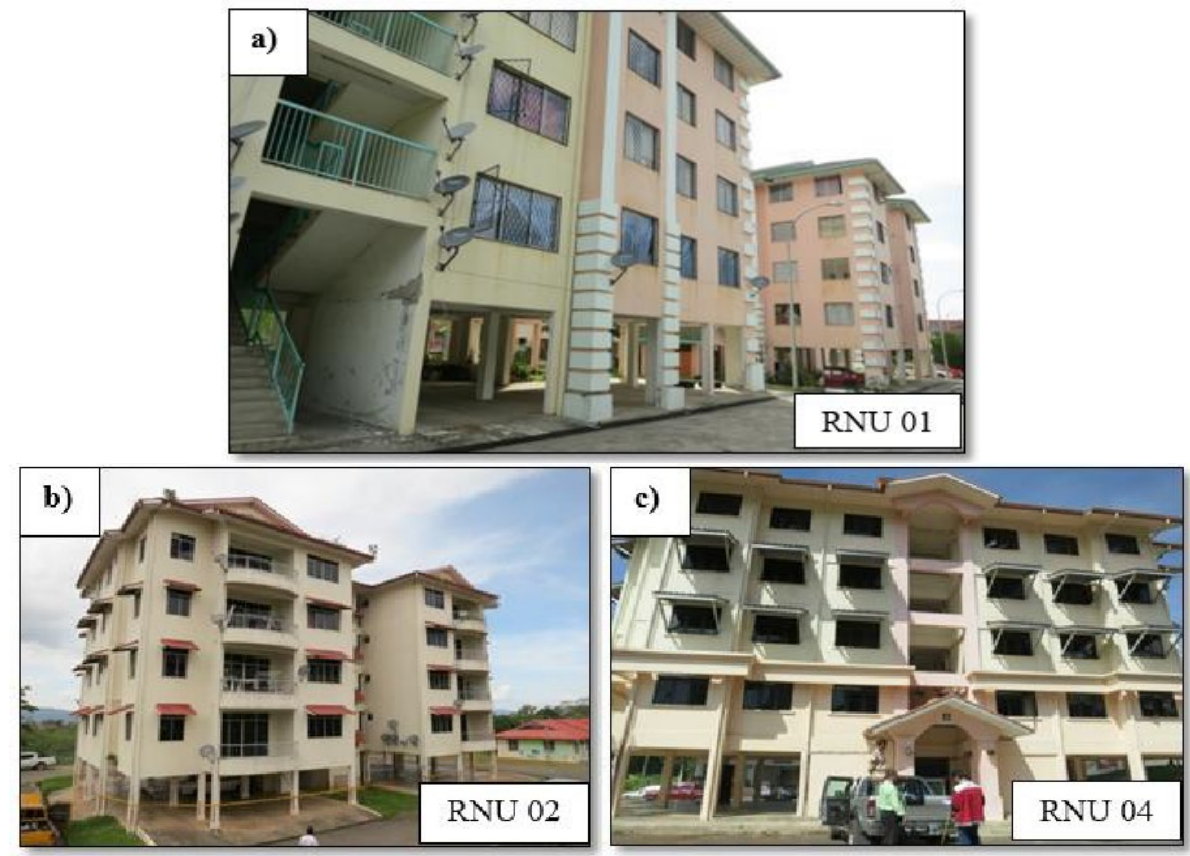

Fig. 12 - Soft-storey building a) RNU 01, b) RNU 02 and c) RNU 04

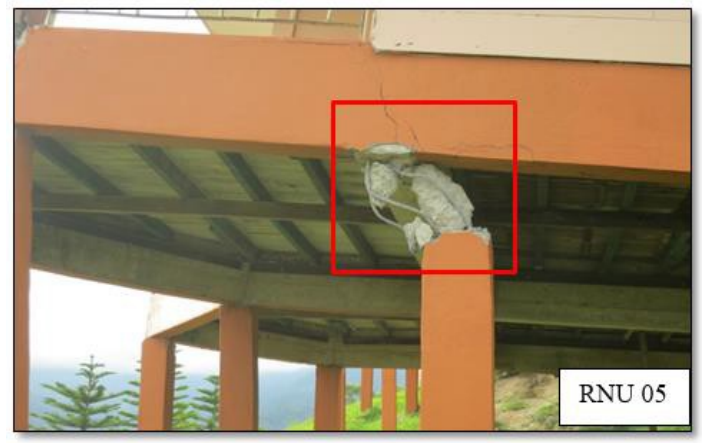

Fig. 13 - Improper transverse reinforcement (link space) causing severe buckling and collapse

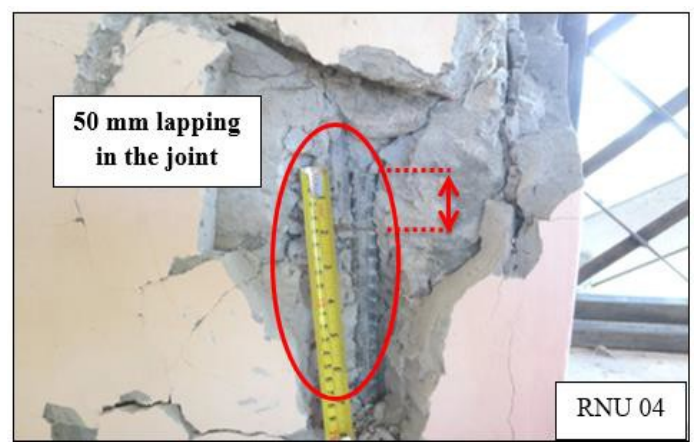

Fig. 14 - Poor and inconsiderable lap length found in joint 


\subsubsection{Inadequate Type and Size of Aggregates}

The crack and spalling of the concrete cover were observed in all the case study buildings due to improper size and type of aggregates that were implemented in the structure, as shown in Fig. 15. Although the damages occurred in the existing buildings, the aggregate size for the combined fine and coarse should range between $5 \mathrm{~mm}$ and $20 \mathrm{~mm}$ [69]. This aggregate does not fulfil the specification in terms of grading, durability, particle shape, surface texture, abrasion and skid resistance, absorption, and surface moisture. The effect of inadequate supervision during the construction period was demonstrated after the main shock, wherein this river stone (smooth surface) did not bond well with the concrete.

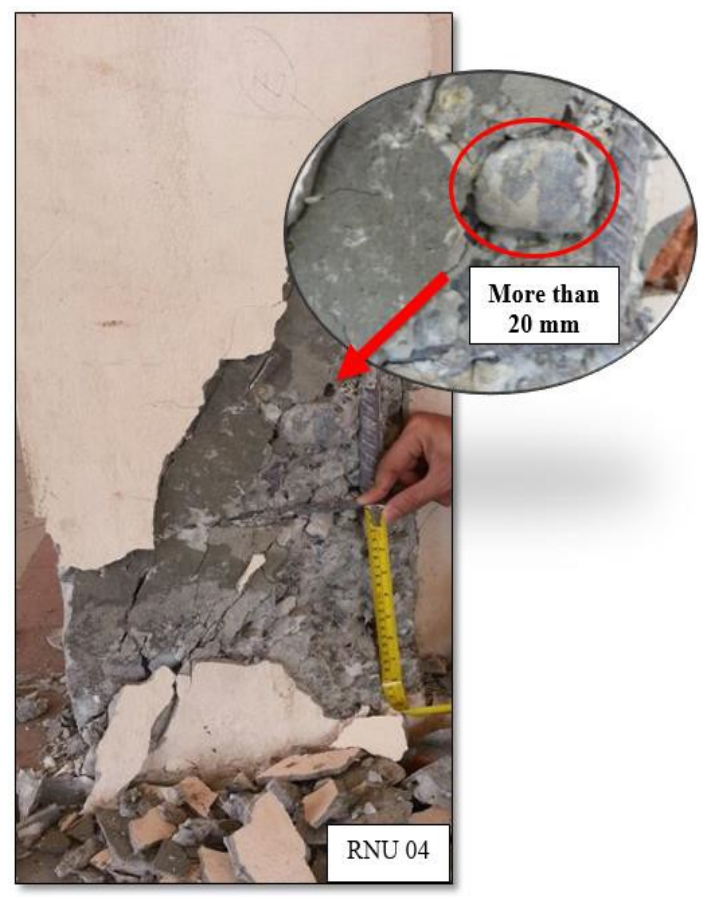

Fig. 15 - Inadequate aggregate size found in the column

\subsection{Proposed Strengthening Method To-Date for Beam-Column Joints}

Most of the severely-damaged existing RC structural buildings in Ranau were not able to retrofit, thus major demolition must be conducted and replaced with a new seismic construction design. The Malaysia's PWD has accepted full responsibility for the design and invention of new construction. Apart from the existing soft-storey buildings where only the beam-column joints are affected, an appropriate strengthening method is required to prolong the span in column area, instead of at the beam and display a strong-column weak-beam mechanism. Nevertheless, a few prominent government and non-government organisations were in a cooperative effort to assist the PWD through several studies. These studies should be able to rectify the problems in all existing and future designs of structural buildings in Ranau.

Various strengthening studies were proposed in several affected countries with moderate to high seismic activities. Nevertheless, these studies were limited to beam-column joints section. All the proposed strengthening studies were thoroughly conducted in full/reduced scale (beam-column joints), as shown in Fig. 16 [10], [70]-[72]. The motive of these strengthening methods refers to high strength and ductility in the joints and effective increase in joint shear strength capacity. The strengthening methods from Fig. 16 (a), (b) and (c) have improved the energy capacity dissipation and reduced stiffness degradation of beam-column joints, however, particular caution need to be handled in detailed, especially for the welded section wherein the brittle/corrosion failure under elevated number of cycles may occur [70]-[75]. Where else for Fig. 16 (d), the capability of this method would relocate the plastic hinge away from the joint section, hence improving the load carrying capacity. The wrapping technique play crucial role around joints which sometimes may mislead to undesired de-bonding failure [10], [76]. Even though costing consumptions were not investigated in detail in these strengthening methods, some of them (steel dissipation jacket and steel cages), especially those associated to non-seismic design of structural beam-column joints, have been visibly adopted in the strongcolumn weak-beam concept. In other cases, retrofitting by using external post tension rods and fibre reinforced polymer had considerably increased the strength of non-seismic design with approximation up to $40 \%$, thus avoiding major brittle shear failure at joints. In addition, this method can improve the seismic performance joints with adequate 
existing reinforcement detailing. Therefore, these strengthening properties can be considered by the local authorities in Malaysia to increase the lifespan of the existing/old structural buildings, instead of demolishing them.
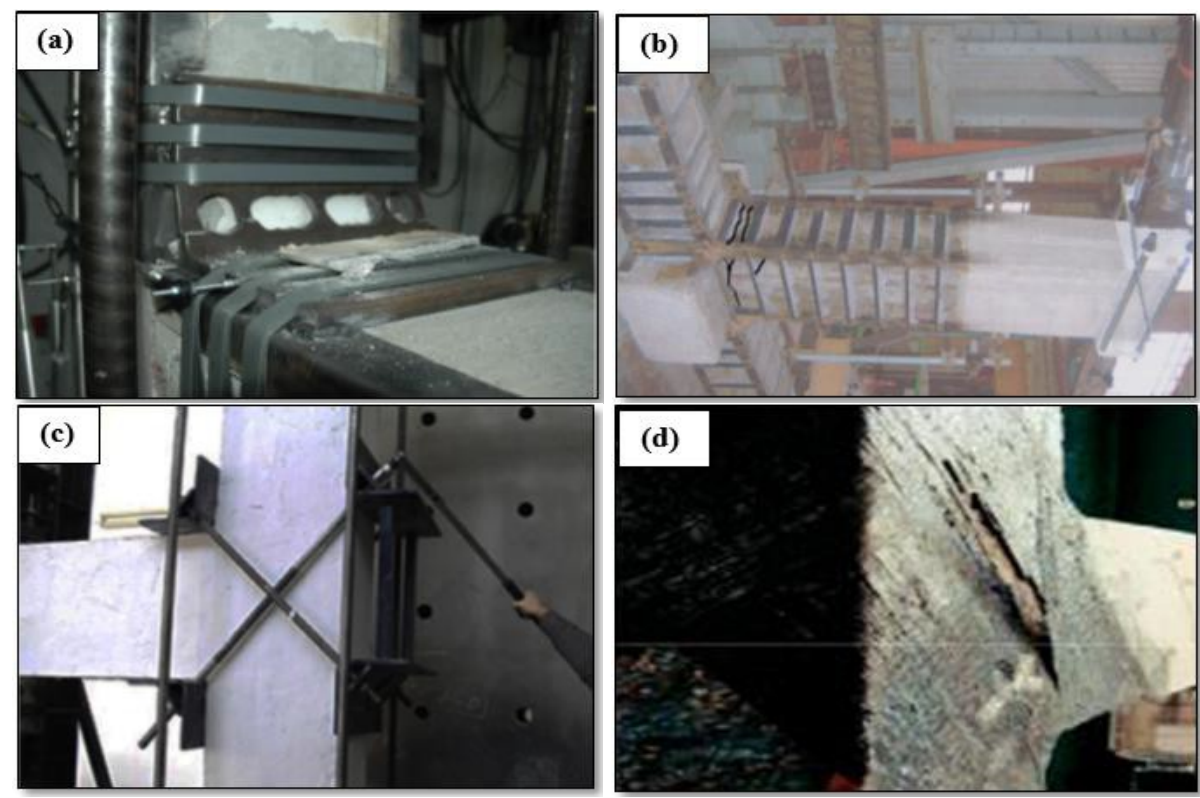

Fig. 16 - Strengthening method proposed to-date at RC beam-column joints (a) retrofitted with steel dissipation jacket [70], (b) externally strengthened with steel cages [71], (c) strengthened using external post-tension rods [72] and (d) retrofitted fibre reinforced polymer (FRP) [10]

\section{Conclusion}

The 5.9 magnitude Ranau earthquake, which occurred in June 5, 2015 at 7:15 am, including the sequential significant number of aftershocks, should be highlighted. Although the recorded ground acceleration motion was low, most parts in the case structural building studies have been affected by the main-shock events. Based on a thorough visual damage observation, the RC buildings can be classified as weak-column strong-beam behaviour due to the severe damages that occurred on the columns, such as spalling of concrete cover and buckling of reinforcement, while the beams only experienced hairline cracks and spalling of plaster. Multi-storey residential buildings have a high potential threat of soft-storey failure mechanism. Indeed, this failure occurred because the bare frame was without infill wall, which was located at the bottom storey of the building. Severe damages on beam-column joints were observed for this kind of structural RC building. Insufficient confinement reinforcement in the critical region within the beamcolumn joints was evident in all case building studies, thereby proving that these buildings were not designed according to the seismic code provision. Therefore, low public awareness and preparedness to earthquake in Malaysia must be improved to minimise the casualties of future earthquakes. Some optional proposed strengthening/retrofitting methods that were presented for this particular structural member have been presented to the local authorities so as to decide in preserving the existing/old buildings. Currently a research proposal has been opted to control the level of damage based on cracking mechanism in reinforced concrete beam-column joints using Artificial Neural Network simulation thus providing a suitable strengthening method for the respective member. In future, studies related to seismic activities may analyse the performance of the existing designs for structural RC beam-column joints members and propose a viable seismic design in Malaysia.

\section{Acknowledgement}

This study was supported by the Research Fund Assistance from the University of Malaya under RU Grant Faculty Program (GPF026A-2018). The author would like to thank University of Tun Hussein Onn Malaysia for providing scholarship under the S.T.A.B scheme (2017) to make this research study a success.

\section{References}

[1] Nordenson, G.J.P., \& Bell, G.R. (2000). Seismic Design Requirements for Regions of Moderate Seismicity, Earthquake Spectra, 16(1), 205-225.

[2] Borghini, A., Gusella, F., \& Vignoli, A. (2016). Seismic vulnerability of existing R.C. buildings: A simplified numerical model to analyse the influence of the beam-column joints collapse, Engineering Structures, 121, 19-29. 
[3] Sanjery, K.A.A.A., Rahman, N.A., \& Baharudin, K.S. (2011). Aspects of Reliability and Quality Management of Buildings in Accordance with Eurocode, Procedia Engineering, 20, 166-173.

[4] BS 8110: Part 1 (1997). Structural Use of Concrete: Code of Practice for Design and Construction, British Standard Institution, UK.

[5] Azuan, T.M., Dora, A.G.K., \& Hayati, A.H.N. (2016). Modeling of two-storey precast building under past earthquake records using Dynaplot program, AIP Conference Proceedings, 1774(1), 030013.

[6] Ashtiani, M.S., Dhakal, R.P., \& Scott, A.N. (2014). Seismic Performance of High-Strength Self-Compacting Concrete in Reinforced Concrete Beam-Column Joints, Journal of Structural Engineering, 140(5), 04014002.

[7] Wang, D., Wang, Z., \& Smith, S.T. (2014). Experimental study on the seismic performance of full-scale interior RC beam-column joints retrofitted with FRP composites, Composite Structures, 159, 397-409.

[8] Masi, A., Santarsiero, G., Lignola, G.P., \& Verderame, G.M. (2013). Study of the seismic behavior of external RC beam-column joints through experimental tests and numerical simulations, Engineering Structures, 52, 207-219.

[9] Ricci, P., De Luca, F., \& Verderame, G.M. (2011). 6th April 2009 L’Aquila earthquake, Italy: Reinforced concrete building performance, Bulletin of Earthquake Engineering, 9(1), 285-305.

[10] Pohoryles, D., Melo, J., Rossetto, T., Varum, H., \& D’Ayala, D. (2017). A realistic full CFRP retrofit of RC beam-column joints compared to seismically designed specimens. Proc. of the 16th World Conference on Earthquake Engineering, pp 1-11.

[11] Ismail, R., Adnan, A., \& Ibrahim, A. (2011). Vulnerability of Public Buildings in Sabah Subjected to Earthquake by Finite Element Modelling, Procedia Engineering, 20, 54-60.

[12] Zanina, P., Yee, D.F.C., \& Muhammad, M.K. (2015). Developing Malaysian Design Standards for Earthquake Resistance, IEM Jurutera Magazine, pp 6-11.

[13] Standards Malaysia (2017). Malaysia National Annex to Eurocode 8: Design of structures for earthquake resistance-Part 1: General rules, seismic actions and rules for buildings, SIRIM Berhad, Malaysia.

[14] Saruddin, S.N.A., \& Nazri, F.M. (2015). Fragility Curves for Low- and Mid-rise Buildings in Malaysia, Procedia Engineering, 125, 873-878.

[15] Osagie, A.U., Nawawi, M., Khalil, A.E., \& Abdullah, K. (2017). Regional travel-time residual studies and station correction from 1-D velocity models for some stations around Peninsular Malaysia and Singapore, NRIAG Journal of Astronomy and Geophysics, 6(1), 19-29.

[16] Bendick, R., Bilham, R., Fielding, E., Gaur, V., Hough, S., Kier, G., Kulkarni, M., Martin, S., Mueller, K., \& Mukul, M. (2001). The 26 January 2001 "Republic Day” earthquake, India, Seismological Research Letters, 72(3), 328-335.

[17] Sooria, S.Z., Sawada, S., \& Goto, H. (2012). Proposal for Seismic Resistant Design In Malaysia: Assessment of Possible Ground Motions in Peninsular Malaysia, Annual of Disas. Res. Ins (55B).

[18] Balendra, T., \& Li, Z. (2008). Seismic hazard of Singapore and Malaysia, Earthquake Engineering in the low and moderate seismic regions of Southeast Asia and Australia, Special Issue-Electronic Journal of Structural Engineering.

[19] Nabilah, A.B., \& Balendra, T. (2012). Seismic hazard analysis for Kuala Lumpur, Malaysia, Journal of Earthquake Engineering 16(7), 1076-1094.

[20] Leydecker, G., \& Kopera, J.R. (1999). Seismological hazard assessment for a site in Northern Germany, an area of low seismicity, Engineering Geology, 52(3-4), 293-304.

[21] Atakan, K., Midzi, V., Moreno, B. T., Vanneste, K., Camelbeeck, T., \& Meghraoui, M. (2000). Seismic hazard in regions of present day low seismic activity: uncertainties in the paleoseismic investigations along the Bree Fault Scarp (Roer Graben, Belgium), Soil Dynamics and Earthquake Engineering, 20(5-8), 415-427.

[22] Balendra, T., Lam, N.T.K., Wilson, J.L., \& Kong, K.H. (2002). Analysis of long-distance earthquake tremors and base shear demand for buildings in Singapore, Engineering Structures, 24(1), 99-108.

[23] Petersen, M.D., Dewey, J., Hartzell, S., Mueller, C., Harmsen, S., Frankel, A., \& Rukstales, K. (2014). Probabilistic seismic hazard analysis for Sumatra, Indonesia and across the Southern Malaysian Peninsula, Tectonophysics, 390(1-4), 141-158.

[24] Han, S.W., \& Choi, Y.S. (2008). Seismic hazard analysis in low and moderate seismic region-Korean peninsula, Structural Safety, 30(6), 543-558.

[25] Lantada, N., Irizarry, J., Barbat, A.H., Goula, X., Roca, A., Susagna, T., \& Pujades L.G. (2010). Seismic hazard and risk scenarios for Barcelona, Spain, using the Risk-UE vulnerability index method, Bulletin of Earthquake Engineering, 8(2), 201-229.

[26] Ornthammarath, T., Douglas, J., Sigbjörnsson, R., \& Lai, C.G. (2011). Assessment of ground motion variability and its effects on seismic hazard analysis: a case study for iceland, Bulletin of Earthquake Engineering, 9(4), 931953.

[27] Anbazhagan, P., Sitharam, T.G., \& Vipin, K.S. (2009). Site classification and estimation of surface level seismic hazard using geophysical data and probabilistic approach, Journal of Applied Geophysics, 68(2), 219-230.

[28] Luin, C., Jeffery, C., \& Peng, M.K. (2011). Gathering of Views and Opinions on Seismic Investigations in Peninsular Malaysia-Report on the IEM Workshop on Earthquake (Part 1), IEM Jurutera Magazine, pp 44-51. 
[29] Geoscience (2004). Newcastle Earthquake, Australia.

[30] Megawati, K., \& Pan, T.C. (2010). Ground-motion attenuation relationship for the Sumatran megathrust earthquakes, Earthquake Engineering \& Structural Dynamics, 39(8), 827-845.

[31] Pappin, J. W., Yim, P. H. I., \& Koo, C. H. R. (2011). An approach for seismic design in Malaysia following the principles of Eurocode 8, IEM Jurutera Magazine, pp 22-28.

[32] Lam, N., Tsang, H.H., Lumantarna, E., \& Wilson, J. (2016). Minimum loading requirements for areas of low seismicity, Geomechanics and Engineering, 11(4), 539-561.

[33] Adnan, A., Hendriyawan, A.M., \& Irsyam, M. (2006). Development of seismic hazard map for Peninsular Malaysia, In-Proceeding on Malaysian Science and Technology Congress, Malaysia.

[34] Hamid, N.H.A., \& Mohamad, N.M. (2013). Seismic Assessment of a Full-Scale Double-Storey Residential House using Fragility Curve, Procedia Engineering, 54, 207-221.

[35] Adnan, A., \& Hendriyawan, H. (2012). Development of peak ground acceleration map of East Malaysia for design response spectra of Bakun Dam, Earthquake Engineering Research Institute 2012 Annual Meeting and National Earthquake Conference, Tennessee.

[36] Lam, N., Tsang, H.H., Looi, D., Lumantarna, E., \& Wilson, J. (2016). Seismic Hazard Modelling for Malaysia, In-Proceeding of the Australian Earthquake Engineering Society Conference, Melbourne, VIC, pp. 1-12.

[37] Stein, S., Geller, R.J., \& Liu, M. (2012). Why earthquake hazard maps often fail and what to do about it, Tectonophysics, (562-563), pp 1-25.

[38] Guevara-Perez, L. T. (2012). Soft story and weak story in earthquake resistant design: A multidisciplinary approach, Retrieved on May 5, 2017 from https://www. iitk. ac. in/nicee/wcee/article/WCEE2012_0183. pdf.

[39] IBC (2000). Dearborn Trade Publishing, International Code Council, Building Officials, Administrators.

[40] ASCE (2012). Seismic Evaluation of Existing Buildings, American Society of Civil Engineers, Reston, Virginia.

[41] Halde, V.V., \& Deshmukh A.H. (2015). Review on behaviour of soft storey in building, International Research Journal of Engineering and Technology, 2(8), 327-329.

[42] Verderame, G.M., De Luca, F., Ricci, P., \& Manfredi, G. (2011). Preliminary analysis of a soft-storey mechanism after the 2009 L'Aquila earthquake, Earthquake Engineering \& Structural Dynamics, 40(8), 925-944.

[43] Romão, X., Costa, A.A., Paupério, E., Rodrigues, H., Vicente, R., Varum, H., \& Costa, A. (2013). Field observations and interpretation of the structural performance of constructions after the 11 May 2011 Lorca earthquake, Engineering Failure Analysis, 34, 670-692.

[44] Bayraktar, A., Altunişik, A.C., \& Pehlivan, M. (2013). Performance and damages of reinforced concrete buildings during the October 23 and November 9, 2011 Van, Turkey, earthquakes, Soil Dynamics and Earthquake Engineering 53, 49-72.

[45] Urich, A., \& Beauperthuy, J. (2012). Protagonism of the infill walls on seismic performance of Venezuela buildings, 15th World Conference of Earthquake Engineering, Lisboa, Portugal.

[46] Hirde, S., \& Tepugade, G. (2014). Seismic Performance of Multistorey Building with Soft Storey at Different Level with RC Shear Wall, International Journal of Current Engineering and Technology, 4(3), 2019-2023.

[47] Komur, M.A. (2016). Soft-Story Effects on the Behavior of Fixed-Base and LRB Base-Isolated Reinforced Concrete Buildings, Arabian Journal for Science and Engineering, 41(2), 381-391.

[48] Agha Beigi, H., Christopoulos, C., Sullivan, T., \& Calvi, M. (2015). Seismic response of a case study soft story frame retrofitted using a GIB system, Earthquake Engineering \& Structural Dynamics, 44(7), 997-1014.

[49] Jennings, E., \& Lindt, J.W.V.D. (2014). Numerical Retrofit Study of Light-Frame Wood Buildings Using Shape Memory Alloy Devices as Seismic Response Modification Devices, Journal of Structural Engineering, 140(7), 04014041.

[50] MMD (2015). Climate Change Scenarios for Malaysia Scientific Report 2001-2099, Numerical Weather Prediction Development Section Technical Development Division, Malaysian Meteorological Department Ministry of Science, Technology and Innovation Kuala Lumpur.

[51] Bernama (2015, June 21). School building in Ranau deemed unsafe after Sabah quake, The Malay Mail, pp 10.

[52] Majid, T.A., Adiyanto, M.I., \& Nazri, F.M. (2014). Nonlinear Response of Low Rise Hospital RC Building in Malaysia Due to Far and Near Field Earthquake, Journal of Civil Engineering Research, 4(3A), 130-134.

[53] USGS (2015). ShakeMap: Sabah, Malaysia, in: M. M 6.0 - 14km WNW of Ranau (Ed.) ANSS Comprehensive Earthquake Catalog (ComCat) Documentation, USA. Retrieved on March 13, 2017 from https://earthquake.usgs.gov/earthquakes/eventpage/iscgem911497/executive

[54] NEIC (2007). Retrieved on March 10, 2017 from Earthquake database website, National Earthquake Information Center, Denver Federal, Colorado.

[55] Faisal, A., Majid, T.A., Ahmad, F., Tongkul, F., \& Sari, S.M. (2011). Influence of large dam on seismic hazard in low seismic region of Ulu Padas Area, Northern Borneo, Natural Hazards, 59(1), 237-269.

[56] JMGM (2006). Seismotectonic of Malaysia, in: Third (Ed.) Minerals and Geoscience Department of Malaysia.

[57] Adnan, A., Marto, A., \& Hendriyawan, H. (2004). Lesson learned from the effect of recent far field Sumatra earthquakes to Peninsular Malaysia, 13th World Conference on Earthquake Engineering (13WCEE) Vancouver, BC, Canada, pp 1-6. 
[58] Hee, M.C., Lee, W.O., Jeffrey, C., Sooi, T.K., Andy, G.K.F., Low, K.C., Adnan, A., Teo, C.W., John, K.R., Liew, S.S., \& Ismail, E. (2005). Position paper on issues related to earthquake, Bulletin of The Institution of Engineers Malaysia.

[59] Rashvinjeet, S.B. (2012, April 15). Shelter from tremors, The Star, pp 18.

[60] Eurocode 8 (2005). Design of structures for earthquake resistance-Part 1: General rules, seismic actions and rules for buildings, European Committee for Standardization; Brussels, Belgium.

[61] Tawfik, A.S., Badr, M.R., \& Eizanaty, A. (2014). Behavior and ductility of high strength reinforced concrete frames, HBRC Journal, 10(2), 215-221.

[62] Sayın, E., Yön, B., Calayır, Y., \& Karaton, M. (2013). Failures of masonry and adobe buildings during the June 23, 2011 Maden-(Elazığ) earthquake in Turkey, Engineering Failure Analysis, 34, 779-791.

[63] Ates, S., Kahya, V., Yurdakul, M., \& Adanur, S. (2013). Damages on reinforced concrete buildings due to consecutive earthquakes in Van, Soil Dynamics and Earthquake Engineering, 53, 109-118.

[64] Lu, X., Urukap, T.H., Li, S., \& Lin, F. (2012). Seismic behavior of interior RC beam-column joints with additional bars under cyclic loading, Earthquake and Structures, 3(1), 37-57.

[65] Saatcioglu, M., Mitchell, D., Tinawi, R., Gardner, N.J., Gillies, A.G., Ghobarah, A., Anderson, D.L., \& Lau, D. (2001). The August 17, 1999, Kocaeli (Turkey) earthquake-damage to structures, Canadian Journal of Civil Engineering, 28(4), 715-737.

[66] Sengel, H.S., \& Dogan, M. (2013). Failure of buildings during Sultandagi Earthquake, Engineering Failure Analysis, 35, 1-15.

[67] Eurocode 2 (2004). Design of Concrete Structures: Part 1-1: General Rules and Rules for Buildings, European Committee for Standardization, Brussels, Belgium.

[68] Celep, Z., Erken, A., Taskin, B., \& Ilki, A. (2011). Failures of masonry and concrete buildings during the March 8, 2010 Kovancılar and Palu (Elazığ) Earthquakes in Turkey, Engineering Failure Analysis, 18(3), 868-889.

[69] BS 882 (1992). Incorporating Amendment No. 1, Specification for aggregates from natural sources for concrete, Third edition, British Standards Institution, UK.

[70] Santarsiero, G., \& Masi, A. (2015). Seismic performance of RC beam-column joints retrofitted with steel dissipation jackets, Engineering Structures, 85, 95-106.

[71] Campione, G., Cavaleri, L., \& Papia, M. (2015). Flexural response of external R.C. beam-column joints externally strengthened with steel cages, Engineering Structures, 104, 51-64.

[72] Yurdakul, Ö., \& Avşar, Ö. (2016). Strengthening of substandard reinforced concrete beam-column joints by external post-tension rods, Engineering Structures, 107, 9-22.

[73] Dang, C.T., \& Dinh, N.H. (2017). Experimental Study on Structural Performance of RC Exterior Beam-Column Joints Retrofitted by Steel Jacketing and Haunch Element under Cyclic Loading Simulating Earthquake Excitation, Advances in Civil Engineering, pp 1-11.

[74] Giuseppe, L.C., \& Andrea, F. (2016). Flexural Behavior of External Beam-Column Reinforced Concrete Assemblages Externally Strengthened with Steel Cages, Structural Journal, 113(05), 883-894.

[75] Shafaei, J., Hosseini, A. \& Marefat, M.S. (2014). Seismic retrofit of external RC beam-column joints by joint enlargement using prestressed steel angles, Engineering Structures, 81, 265-288.

[76] Dalalbashi, A., Eslami, A., \& Ronagh, H.R. (2012). Plastic hinge relocation in RC joints as an alternative method of retrofitting using FRP, Composite Structures, 94(8), 2433-2439. 